


\section{ILLEGAL CONTROL OVER THE TERRITORY IN INTERNATIONAL LAW AND THE STATUS OF DONBAS DETERMINATION}

Russia's armed aggression against Ukraine since 2014 has, among other consequences, led to a temporary loss of government control over Donbass. In this regard, a number of issues arose: how to stop aggression, human suffering, restore the territorial integrity of Ukraine; how to legally determine the status of territories over which control is temporarily lost; how to legally determine the responsibility of the aggressor for his actions in Donbass. All these are very complicated by the unofficial nature of Russian aggression.

It is clear that the answers should be sought in international law. But after a total prohibition on aggressive warfare under the UN Charter, virtually all aggressive actions by states occupying territories are carried out unofficially, by supposedly independent groups, with the creation of formally independent political entities. In these conditions, there occurs an interpretation of existing and search for new concepts and approaches designed to qualify illegal forms of control of one state over the territory of another state.

This article is devoted to the practical issue of determining the legal status of the territory of Donbass, over which the government temporarily has lost control. But the authors also propose the idea of a new vision of the institution of illegal exercise of control of one state over the territory of another state and demonstrate the difficult issues of correlation and interaction of conventional, judicial international law, and the doctrine of the latter. The methods used in the article are integrated by a single both inductive and deductive reconstruction approach that combines systemic and functional elements.

\section{FORMS OF ILLEGAL CONTROL OVER THE TERRITORY IN INTERNATIONAL LAW}

The protracted conflict in eastern Ukraine and the loss of control by the Ukrainian Government over certain districts of Donetsk and Luhansk oblasts (known as ORDLO abbreviation) have a very significant impact on the realization of the human rights 
of the inhabitants of these territories. Also the status of ORDLO in international and national law is of fundamental importance for determining the peculiarities of the implementation of these rights and the responsibility for their violation. But, of course, the issue of the legal status of ORDLO and similar territories is even more important in the context of international and national security.

It is important to understand that the conflict and the loss of Government control over ORDLO, which do not raise objections and are beyond doubt, in no way mean the loss of Ukraine's sovereignty over these territories. As noted by the classic of international law I. Brownlie in 1966, citing specific examples, it is not difficult for courts to separate the sovereignty of the state and legal rights to certain territories from the exercise of real and effective jurisdiction on them by other actors (Brownlie, 2003: 112).

At the same time, the temporary legal regime of such territories in this situation should be determined, classified to define the status of the population and applicable legal remedies. According to Brownlie, apart from the question of sovereignty, the practical necessity to avoid a legal vacuum on a given territory dictates the need to link jurisdiction with the recognition of the effective exercise of power and the corresponding "sphere of legal competence" of de facto power: "Ultimately territory cannot be distinguished from jurisdiction for certain purposes. Both terms refer to legal powers, and, when a concentration of such powers occurs, the analogy with territorial sovereignty justifies the use of the term 'territory' as a form of shorthand" (Brownlie, 2003: 112-113). In this approach, in our opinion, we can assume that illegal control over the territory is a generic concept, and specific legal regimes for it, such as occupation, are forms of control execution.

Occupation. The regime of military power over the territory of an enemy country, identified with the occupation, was defined in the Regulations Concerning the Laws and Customs of War on Land, which is Annex to the IV Hague Convention Respecting the Laws and Customs of War on Land of 1907. In particular, the territory is considered occupied when it is actually occurred under the powers of the enemy army; occupation extends only to the territory where such power has been established and can be exercised (Article 42). The powers of the legitimate authority de facto pass into the hands of the occupier, who must take all available measures to maintain and ensure, as far as possible, public order and security, while respecting, except where this is completely impossible, the applicable law of the country (Article 43). At the same time, the citizenship of the residents must remain unchanged, unless they (individually) decide otherwise (Article 45). According to this Regulation (Article 1) and the IV Hague Convention itself (Article 3), not only the regular army but also the "militia" and "volunteer corps," which are part of its armed forces, may act (and therefore exercise occupation and military power) on behalf of the occupying power, if these formations are headed by commanders responsible for subordinates, have fixed distinctive emblems, openly carry weapons, "conduct their operations in accordance with the laws and customs of war" (Convention IV, 1907; Annex to Convention IV, 1907; De Mulinen, 1987; Vitoshynskyi, 2014).

Under the Geneva Convention (IV) Relative to the Protection of Civilian Persons in Time of War of 1949, partial or complete occupation of the territory of a State is recognized as such even if it does not meet with armed resistance and the state of war 
between the occupied (partially or completely) state and the occupying state is not recognized by one of them (Article 2) (Convention IV, 1949). And the authoritative Commentary of the International Committee of the Red Cross (ICRC) to this Convention (1958), used by international tribunals, indicates that even non-recognition of a state of war by all parties to an armed conflict does not preclude application of the Convention and recognition of occupation:

"In case of war being declared or of armed conflict, the Convention enters into force; the fact that the territory of one or other of the belligerents is later occupied in the course of hostilities does not in any way affect this; the inhabitants of the occupied territory simply become protected persons as they fall into the hands of the Occupying Power" (Commentary of 1958).

Applicability of Article 2 of the Geneva Convention (IV) Relative to the Protection of Civilian Persons in Time of War of 1949 (as well as the Convention as a whole, the Additional Protocol (Protocol I) thereto and the Regulations Concerning the Laws and Customs of War on Land of 1907) to the population of the occupied territories regardless of the state of war is recognized or not is confirmed also by the Advisory Opinion of the International Court of Justice on the Legal Consequences of the Construction of a Wall in the Occupied Palestinian Territory (Advisory Opinion, 2004).

Similarly, Article 4 of the Geneva Convention (IV) Relative to the Protection of Civilian Persons in Time of War of 1949 does not extend the protection on nationals of a belligerent enemy State - residents of the occupied territories, "while the State of which they are nationals has normal diplomatic representation in the State in whose hands they are" (Convention IV, 1949), but the ICRC Commentary on this article states:

"...all the particular cases we have just been considering confirm a general principle
which is embodied in all four Geneva Conventions of 1949. Every person in enemy
hands must have some status under international law: he is either a prisoner of war
and, as such, covered by the Third Convention, a civilian covered by the Fourth
Convention, or again, a member of the medical personnel of the armed forces who is
covered by the First Convention. There is no intermediate status; nobody in enemy
hands can be outside the law."

In addition, it is stated that the existence of "normal diplomatic representation" does not mean freedom of action and freedom of movement of diplomats in the occupied territories in order to visit compatriots and provide them with assistance (Commentary of 1958). This position was adopted by the International Criminal Tribunal for the Former Yugoslavia in 2000 in The Prosecutor v. Tihomir Blaškic. The Tribunal noted that even in cases where diplomatic relations between the two belligerents persist, their nationals may have the status of protected persons under international humanitarian law, and in particular the IV Geneva Convention, from the moment they lose or cannot otherwise enjoy diplomatic protection (International Tribunal, Blaškic, 2000).

According to Article 6 of the Geneva Convention (IV) Relative to the Protection of Civilian Persons in Time of War of 1949, the essential qualifying feature of the occupation is "that such Power exercises the functions of government in such territory," which may take place both during and after the war. Similarly, the legal regime of occupation with the intended status of the inhabitants of the territory as protected persons 
lasts as long as the occupying power is exercised over it and the inhabitants are not released, repatriated and restored to their rights (Convention IV, 1949).

According to Article 29 of the Convention, the state is responsible for the actions of its "agents" in the occupied territories. In this case, the status of the territory as occupied and the corresponding status of its inhabitants as protected persons do not change either in the case of changes in the institutions or government of the territory, or the conclusion of an agreement between the authorities of the occupied territory and the occupying state, or annexation of this territory by the occupying state (Article 47) (Convention IV, 1949). As stated in the ICRC Commentary to this article, "Agreements concluded with the authorities of the occupied territory represent a more subtle means by which the Occupying Power may try to free itself from the obligations incumbent on it under occupation law" (Commentary of 1958).

The Additional Protocol (Protocol I) to the Geneva Convention (IV) Relative to the Protection of Civilian Persons in Time of War of 1949 confirms that the occupation of the territory does not change its legal status (Article 4) (Protocol, 1977).

Under general international law, the military occupation of a state as a result of the use of force in violation of the UN Charter is prohibited, as is the organization and encouragement of irregular forces or armed gangs, including mercenaries, to invade another state. No acquisition of territories as a result of a threat or use of force is recognized (Declaration on Principles of International Law concerning Friendly Relations and Co-operation among States in accordance with the Charter of the United Nations of 1970).

According to the Definition of Aggression of 1974 any military occupation, however temporary, and regardless of a declaration of war, or any annexation by the use of force of the territory of another State or part thereof qualified as acts of aggression - "the use of armed force by a State against the sovereignty, territorial integrity or political independence of another State." The qualification of occupation does not change depending on whether the act was carried out by the regular armed forces, or by sending by the state, or on behalf of the state, or with significant state involvement of armed gangs, groups, irregular forces or mercenaries. No acquisition of territories as a result of aggression is and cannot be recognized as lawful (Articles 1, 3, 5) (Definition, 1974).

Summing up the regulation of occupation in international law, V. Tolstyh notes: "In the case of occupation, there is a replacement of the actor that performs state functions... Some elements of public order, created by the previous government, are preserved (norms of civil, labor and criminal law, the status of officials and judges, etc.). The occupying state, however, may subject the population of the occupied territory to the provisions essential to maintain the normal administration of the territory and ensure the security of the occupying state" (Tolstyh, 2010: 799-800).

Other forms of illegal control. But occupation is not the only form of illegal control or military power realization over the territory of another state or part of it. Other, related and not completely demarcated forms are overall, general, effective, de facto control.

In The Prosecutor v. Tihomir Blaškic the International Criminal Tribunal for the Former Yugoslavia in 2000 noted that a state may not formally occupy part of the ter- 
ritory of another state, but actually exercise occupation through overall control over armed formations, support and close ties with them. The same logic applies here as in determining the international nature of the conflict - overall control is equal to occupation (International Tribunal, Blaškic, 2000).

In The Prosecutor v. Duško Tadic the International Tribunal for the Former Yugoslavia in 1999, based on the practice of international courts, substantiated the characteristics of state-controlled armed groups (armed forces, militia, paramilitary associations), separating them from, for example, national liberation movements. It is not enough to have financial support and military equipment of the state - it should be proved that the state exercises overall control "by coordinating or helping in the general planning of its [group] military activity." "Only then can the State be held internationally accountable for any misconduct of the group."

However, the state does not necessarily have to give instructions or orders to the leader or members of the group to commit specific acts, to direct or plan each individual operation that violates international law.

"The control required by international law may be deemed to exist when a State (or, in the context of an armed conflict, the Party to the conflict) has a role in organizing, coordinating or planning the military actions of the military group, in addition to financing, training and equipping or providing operational support to that group. Acts performed by the group or members thereof may be regarded as acts of de facto State organs regardless of any specific instruction by the controlling State concerning the commission of each of those acts."

For comparison: individuals and groups not organized into military structures, in order to be considered de facto representatives of a state, must not only be under overall or general control, but also follow certain instructions or directives on the commission of specific acts or their actions should be publicly approved after their commission (International Tribunal, Tadić, 1999).

UN General Assembly Resolution of 1983 "Responsibility of States for Internationally Wrongful Acts," prepared by the International Law Commission and having a doctrinal character, but enjoying considerable authority, stipulates that the behavior of a group of persons under de facto control of a state (instructions, guidance or control) has to be considered as the activity of this state (Article 8). The forms of such behavior of the group include the "actual exercise of elements of state power" in the absence or incapacity of official power (Article 9). At the same time, the implementation of effective control over such a group by the state places the responsibility on the latter; in the absence of such control, the group itself is responsible for its activities, which can be institutionalized as an insurgent or other movement, become a new government of the state or create a new state in part of the old state territory (Article 10). Therefore, the exact qualification of state control over the activities of the group is very important (Responsibility, 1983).

Aspects of effective state control over the territory or part of the territory of another state are developed in the law of the European Court of Human Rights. In particular, the ECHR in Al-Skeini and Others v. The United Kingdom in 2011 noted, also referring to its previous practice: although the jurisdiction of the state under Article 1 of the European Convention on Human Rights is territorial, but one of the exceptions is when 
"a State Party had effective control of an area outside its own territory" (the principle of "effective control of an area"), and this applies to cases where both the state that exercising control and the state whose territory is controlled are parties to this Convention. After all, "the Convention operated essentially within its own regional sphere and permitted no vacuum within that space." Another related condition is control over the authorities of the territory, including military authorities (the principle of "State agent authority").

At the same time, occupation is seen as one of the forms of effective control exercise over the territory, and the Hague conventions operation - as one that applies to all cases of effective control.
"Another exception to the principle that jurisdiction under Article 1 [of the Conven- tion] is limited to a State's own territory occurs when, as a consequence of law- ful or unlawful military action, a Contracting State exercises effective control of an area outside that national territory. The obligation to secure, in such an area, the rights and freedoms set out in the Convention, derives from the fact of such control, whether it be exercised directly, through the Contracting State's own armed forces, or through a subordinate local administration... Where the fact of such domination over the territory is established, it is not necessary to determine whether the Contract- ing State exercises detailed control over the policies and actions of the subordinate local administration. The fact that the local administration survives as a result of the Contracting State's military and other support entails that State's responsibility for its policies and actions."

The exercise of effective control by the state outside its own territory is a matter of fact, which is established primarily on the basis of the strength of its military presence in the territory. Other indicators may also be relevant, in particular, "the extent to which its military, economic and political support for the local subordinate administration provides it with influence and control over the region" (European Court, 2011).

In the Cyprus v. Turkey case in 2001, the ECHR established that the Turkish Republic of Northern Cyprus is not an independent state but is under the effective and overall control of Turkey. The latter ensures the survival of the administration of this territory, providing it with military and other support. Accordingly, Turkey exercises illegal control over part of the territory of Cyprus (Lishchyna, 2016).

In the Ilasscu and Others v. Moldova and Russia case in 2004 ECHR pointed out that during the conflict in Moldova, the Russian Federation carried out the military, political and diplomatic support to the Transnistrian separatists, became a party to the ceasefire agreement in 1992. Therefore, the Court believes, that the responsibility of the Russian Federation comes from illegal actions of Transnistrian separatists, taking into account the support of these actions by Russia. Thus, the Russian Federation contributed in establishing the separatist regime in Transnistria and still supports it. Due to this, the ECHR concluded that the territory of the Transnistrian Moldavian Republic is subject to the jurisdiction of the Russian Federation, its effective control exercise (European Court, 2004; Zadorozhnii, 2015: 337-338; Lishchyna, 2016). This conclusion is, in fact, confirmed in the judgment in Turturica and Casian v. the Republic of Moldova and Russia in 2016, given that the Transnistrian separatist regime cannot survive without Russia's military, economic and political support (Rosiyska, 2016). 
In the judgment in Chiragov and Others v. Armenia in 2015 ECHR noted that Armenia was involved in the Nagorno-Karabakh conflict through direct military presence, military supplies and consultations, and this support, as well as financial and political, is crucial for maintaining the separatist regime in this area; Armenia and Karabakh to a certain extent are administratively integrated. Therefore, in essence, Armenia exercises effective control over the latter (Lishchyna, 2016).

Experts of the Ministry of Reintegration of the Temporarily Occupied Territories of Ukraine with the use of materials of the ICRC, the Council of Europe and the ECHR proposed a comparative characteristic of elements of the occupation and effective control exercise over the territory:

1. Occupation provides for the establishment of power and the activities of one State on the territory or part of the territory of another State, even if it does not meet with any armed resistance. Effective control by the aggressor state presupposes the conduct of continuous hostilities by non-state armed groups against the government forces of one state, with the support of another state, without which the said groups would not be able to carry out their activities. In particular, such support can be political, military, economic, financial, social.

2. In the case of occupation, the occupying state creates the bodies of the occupying power. Effective control provides that non-state armed groups may establish "authorities" with the support of foreign state that cooperates with these "authorities" and may delegate its representatives to them.

3. The existence of occupation is stated by virtue of the very fact of establishing the power of one state over the territory or part of the territory of another state. Recognition of the occupation is not required in court. The existence of effective control is ascertained by international judicial institutions, provided that it is duly proved by a state on the territory of which non-state armed groups operate with support of another state.

4. The four Geneva Conventions for the protection of victims of war, the First Additional Protocol thereto, The Hague Regulations on the Laws and Customs of War on Land and other provisions of the so-called "Hague Law" governing the means and methods of warfare apply to the occupied territories. Effective control is established by international judicial institutions, so each of them determines its own criteria for proving it. In case if effective state control over non-state armed groups proved and its recognition by the international judicial institution to which the relevant claim / application was made, the four Geneva Conventions for the protection of victims of war, the First Additional Protocol and the "Hague Law" are applicable because the existence of an international armed conflict was determined.

5. In the event of occupation, the occupying state shall be responsible for violations of the abovementioned international humanitarian law rules. In the case of effective control, the state that provided support to non-state armed groups is responsible for violations of international humanitarian law norms by these groups. Responsibility for non-compliance with its obligations to protect human rights other than the above-mentioned norms of international humanitarian law lies with the state on the territory of which non-governmental armed groups supported by another state operate (Okupatsiia, 2017). 
In addition, experts from this Ministry point to the following elements of illegal effective control exercise over the territory of another state: a) military control: promoting the creation of separatist armed forces, the presence of its own armed forces, illegal deployment, participation in hostilities, transfer of weapons and infrastructure, warehouses weapons support, support for the development of the armed industry by state firms; b) political control: public statements by military commanders, political statements by leaders, high-level meetings, granting citizenship, participation in elections, military parades and other public events, secret negotiations on the management of weapons warehouses, participation in arrests, detentions, moving of persons and their transfers to separatist "police"; c) economic and financial control: agreements on economic cooperation, debt reduction, gas and energy supplies with more favorable terms than for the rest of the country, giving separatists a part of the income from the sale of military equipment, fixing the amount of financial assistance to separatists in official sources, "acquisition of ownership of the largest separatist enterprise," opening of separatist bank accounts in the Central Bank; d) social control - humanitarian aid (social benefits, pensions, meals in schools, hospitals, prisons) (Deiaki, 2017).

\section{THE PROBLEM OF DETERMINING THE LEGAL STATUS OF THE TERRITORY OF ORDLO}

\section{Qualification of the status of the territory of ORDLO in the Ukrainian legislation}

Qualification of the status of the territory of ORDLO in the legislation of Ukraine is rather difficult. Consider it chronologically and regardless of the types of regulations.

The territory of ORDLO in August 2014 was defined as "the area of the anti-terrorist operation" (Law of Ukraine "On the Administration of Justice and Criminal Proceedings in Connection with the Anti-Terrorist Operation” №1632-VII of 12.08.2014). At the same time, the following were recognized: impossibility to administer justice by some courts (Article 1), impossibility to carry out pre-trial investigation (Article 2). According to the Law of Ukraine "On the Special Order of Local Self-Government in Certain Districts of Donetsk and Luhansk oblasts" (№1680-VII of 16.09.2014), the said order was established temporarily with the date of its termination (prolonged several times); the area of the effect of the law, which was called "certain districts of Donetsk and Luhansk oblasts," was to be determined by a decision of the Verkhovna Rada of Ukraine (Article 1). The conflict in this area called "events, which had a place in the Donetsk, Luhansk oblasts" (Article 3). "The list of settlements on the territory of which the bodies of state power temporarily not exercise their powers" was approved by the Cabinet of Ministers of Ukraine (Order from 07.11.2014 №1085-p). In the Resolution of the Verkhovna Rada of Ukraine on Approval of Appeals on Behalf of Ukraine to the Security Council of the United Nations and the Council of the European Union Concerning the Deployment of an International Peacekeeping Operation in Ukraine (№253-VIII of March 17, 2015), the conflict was called "the crisis situation, 
which has developed in certain districts of Donetsk and Luhansk oblasts." The conflict is defined as merely a "situation" in ORDLO by the Law of Ukraine "On Creating Necessary Conditions for Peaceful Settlement of the Situation in Certain Districts of Donetsk and Luhansk Oblasts” (№2167-VIII of October 6, 2017).

However, in Resolution of the Verkhovna Rada of Ukraine "On the Appeal to the United Nations, European Parliament, Parliamentary Assembly of the Council of Europe, the NATO Parliamentary Assembly, the OSCE Parliamentary Assembly, the Parliamentary Assembly of GUAM, National Parliaments of the World on the Recognition of the Russian Federation as State Aggressor" (№ 129-VIII of January 27, 2015) and in the Resolution of the Verkhovna Rada of Ukraine "On Recognition by Ukraine of Jurisdiction of the International Criminal Court on Crimes against Humanity and War Crimes Committed by Senior Officials of the Russian Federation and "DPR" and "LPR" Terrorist Organizations Leaders, Which Led to Particularly Serious Consequences and Mass Murder of Ukrainian Citizens” (№ 145-VIII of February 4, 2015) it was determined that ORDLO is the occupied territory and at the same time the territory controlled by the terrorist organizations "DPR" and "LPR," which are supported (logistics, supply of weapons, equipment and manpower) by Russian Federation. The latter in such and other forms commits military aggression against Ukraine (also - armed aggression, undeclared war).

According to the Resolution of the Verkhovna Rada of Ukraine "On Recognition of Certain Districts, Cities, Towns and Villages of Donetsk and Luhansk Oblasts as Temporarily Occupied Territories" (254-VIII of March 17, 2015), the territory of ORDLO was recognized as temporarily occupied territories - "until all illegal armed groups, Russian occupation troops, their military equipment, as well as militants and mercenaries withdraw from the territory of Ukraine and the restoration of full control of Ukraine over the state border of Ukraine."

Resolution of the Verkhovna Rada of Ukraine "On Repelling Armed Aggression of the Russian Federation and Overcoming Its Consequences” (№ 337-VIII of April 21, 2015) calls the creation of "DPR" and "LPR" in April 2014 the second (after the occupation of Crimea) phase of armed aggression (and aggressive war) of Russian Federation against Ukraine committed by armed gang formations (or units of mercenaries), controlled, managed and funded by special services of the Russian Federation and systematically backed with its irregular armed formations, Russian mercenaries among servants of the Armed Forces of the Russian Federation released in the reserve. It also pointed to the systematic supply of weapons and military equipment by the Russian Federation. From 27 August 2014 ongoing third phase of armed aggression - massive invasion on the territory of Donetsk and Lugansk oblasts of special forces and regular units of the Armed Forces of the Russian Federation. In qualifying the crimes committed by representatives of the Russian Federation, the Resolution addressed in detail the acts of international humanitarian law.

Resolution of the Verkhovna Rada of Ukraine "On Retreat of Ukraine on Certain Obligations, Defined by the International Covenant on Civil and Political Rights and the Convention on the Protection of Human Rights and Fundamental Freedoms" (№ 462-VIII of May 21, 2015) indicates armed aggression of the Russian Federation, which consists in the introduction into the territory of ORDLO of illegal armed forma- 
tions (terrorist formations), guided, controlled and financed by the Russian Federation, as well as Russian occupation troops. This qualified as the de facto occupation and control of part of the territory (it is defined as the occupied territory) of Ukraine.

The Law of Ukraine "On Ensuring the Rights and Freedoms of Citizens and the Legal Regime in the Temporarily Occupied Territory of Ukraine" (№ 1207-VII of April 15, 2014) action from the beginning comprised only the territory of Crimea and Sevastopol, but in 2018 it was extended to ORDLO. It states that:

\begin{abstract}
"stay on the territory of Ukraine of divisions of the armed forces of other countries with violation of procedures, defined by the Constitution and laws of Ukraine, the Hague Conventions of 1907, IV Geneva Convention of 1949, and also contrary to the Memorandum on guarantees of security in connection with the accession of Ukraine to the 1994 Treaty on the Non-Proliferation of Nuclear Weapons, the Treaty of Friendship, Cooperation and Partnership between Ukraine and the Russian Federation of 1997 and other international legal acts is the occupation of part of the territory of the sovereign state of Ukraine" (preamble).
\end{abstract}

Both in the title of the law and in its text, this occupation is defined as temporary. The temporarily occupied territory of Ukraine remains an integral part of the territory of Ukraine, which is covered by the Constitution and laws of Ukraine (Article 1). Forced automatic entry by Ukrainian citizens, who live on temporarily occupied territory, into citizenship of the Russian Federation is not recognized by Ukraine and is not grounds for loss of citizenship of Ukraine (Article 5). State authorities and bodies of local self-government, formed according to the Constitution and laws of Ukraine, and their officials act on the temporarily occupied territory only on the basis, within the powers and in a way, that provided for by the Constitution and laws of Ukraine (Article 9). Any bodies, their officials on the temporarily occupied territory and their activities are considered illegal if these bodies or entities were created, elected or appointed in a way not prescribed by law; any act (decision, document), issued by such bodies and/ or persons is void and does not create legal effects (Articles 9, 11).

According to the Law of Ukraine "On Peculiarities of State Policy to Ensure State Sovereignty of Ukraine in the Temporarily Occupied Territories in Donetsk and Luhansk Oblasts" (№2268-VIII of January 18, 2018), the Russian armed aggression began with undeclared and covert invasions into Ukraine of armed forces and other agencies units of the Russian Federation, irregular illegal armed formations, armed gangs and groups of mercenaries created, subordinated, guided and financed by the Russian Federation, as well as by organizing and supporting the terrorist activities. One of the consequences of the armed aggression of the Russian Federation was the temporary occupation and general control execution over a part of the territory of Ukraine, which does not create any territorial rights for the Russian Federation. At the same time, the occupation administration of the Russian Federation consists of its state bodies and structures functionally responsible for the administration of the temporarily occupied territories of Ukraine, and self-proclaimed bodies controlled by the Russian Federation, which usurped power functions in the temporarily occupied territories of Ukraine. The activity of this administration is illegal and its issued acts are void, except for the documents, which confirm the fact of birth or death of a person on temporarily occupied territories (Preamble, Articles 1, 2). 
The boundaries of the temporarily occupied territories of ORDLO, according to the Decree of the President of Ukraine №32/2019 of 07.02.2019, "are determined by the actual line of demarcation of the parties."

It should also be noted that in the case before the UN International Court of Justice over the shooting down of MH17 in 2014, Ukraine insists on military and financial support from Russia for illegal armed groups on the territory of ORDLO, which may indicate its effective control over this territory (Mizhnarodnyi, 2017). In the statements of Ukraine against the Russian Federation submitted to the ECHR, the control of Russia over the ORDLO is characterized either as factual or as effective (Formuliuvannia, 2017).

\section{Qualification of the status of the territory of ORDLO in international legal acts and courts decisions}

The Minsk Agreements of 2014-2015 are important for determining the parties to the conflict in eastern Ukraine and the status of the ORDLO. They are bilateral international agreements mediated by the OSCE and confirmed by the UN Security Council. The first agreement of 5 September 2014, "Protocol of the Trilateral Contact Group Consultations," addresses two sides in the conflict. They are not named, but the authorized parties mentioned in the document are Ukraine and the Russian Federation, and they, together with the OSCE Ambassador, are the two authorized signatories. It is clear that the "persons," "illegal military formations," "militants" and "mercenaries" mentioned in the agreement cannot be recognized as parties to the conflict and as parties to the agreement (Protokol, 2014).

However, the "Memorandum on the Implementation of the Protocol of the Trilateral Contact Group Consultations" of September 19, 2014 indicates the withdrawal from the territory of Ukraine of "foreign military units... militants and mercenaries," recalls "representatives of certain districts of Donetsk and Luhansk oblasts." The presence of such formations underscores the international element in the conflict. The presence of "representatives of certain districts" is a rather complex wording, but it does not provide for the recognition of these districts as a party to the conflict, as the format of the Tripartite Group has not changed, the document itself is subordinate to the agreement of September 5, the role of "representatives of districts" is reduced to technical functions (Memorandum, 2014).

Instead, the "Complex of Measures to Implement the Minsk Agreements" of February 12, 2015 calls the parties to the military confrontation Ukrainian troops and "armed formations of certain districts of Donetsk and Luhansk oblasts of Ukraine." Ukraine also undertakes to consult with "representatives of certain districts of Donetsk and Luhansk oblasts" in order to achieve a "universal political settlement," to coordinate with them the legal regulation of local self-government and of elections organization to local self-government bodies in these districts. However, it is not specified to whom the "armed formations of certain districts of Donetsk and Luhansk oblasts of Ukraine" are subordinated, who are "representatives of certain districts of Donetsk and Luhansk oblasts," it is confirmed that ORDLO is part of Ukraine, the format of 
the Tripartite Group has not changed, the need to withdraw foreign armed formations and mercenaries from the territory of Ukraine still mentioned, the disarmament of "all illegal groups" is envisaged (Kompleks, 2015; Minski, 2017).

Finally, the qualification of the conflict in eastern Ukraine and the related status of ORDLO is contained in the decisions of international organizations. UN Security Council Resolution 2202 of 17 February 2015 reaffirmed respect for Ukraine's sovereignty, independence and territorial integrity. Calling the events in Donetsk and Luhansk oblasts a crisis, it supported the "Complex of Measures to Implement the Minsk Agreements" of February 12, 2015 (Resolution 2202, 2015).

UN Security Council Resolution 2166 of 21 July 2014 recognized that the crash site of the MH-17 and the surrounding area are controlled by armed groups engaged in military activities (Resolution 2166, 2014).

PACE Resolution 2132 (2016) of 12 October 2016 "Political Consequences of Russian Aggression in Ukraine" emphasized that this aggression began in 2014 and led to the violation of Ukraine's sovereignty and territorial integrity. Forms of this external aggression were the illegal annexation of Crimea and "Russia's support for separatists in eastern Ukraine and its growing role in the ongoing conflict." It indicates the presence of Russian troops, mercenaries and weapons in eastern Ukraine and the military supply of separatists by Russia (Political, 2016).

PACE Resolution 2133 (2016) of 12 October 2016 "Legal Remedies for Human Rights Violations on the Ukrainian Territories Outside the Control of the Ukrainian Authorities" refers to "the military intervention by Russian forces in eastern Ukraine" in violation of international law. It is noted that the self-proclaimed "DPR" and "LPR" are created, maintained and effectively controlled (as well as de facto controlled) by the Russian Federation and have no legitimacy under international law. The same applies to their "institutions," including "courts" established by the de facto authorities. Effective control here is

"based on the crucial and well-documented role of Russian military personnel in taking over and maintaining power in these regions, against the determined resistance of the legitimate Ukrainian authorities, and on the complete dependence of these regions on Russia in logistical, financial and administrative matters" (Legal, 2016).

It is worth noting that the report of the PACE Committee on Legal Affairs and Human Rights, which became the basis of Resolution 2133, contains even stricter wording on effective control of the Russian Federation in ORDLO: "de facto authorities and their Russian handlers" and others (Council, 2016).

As highlighted in the comment of the Ministry of Reintegration of the Temporarily Occupied Territories of Ukraine on Resolution 2133, this is the first international document that recognized the Russian Federation as a party to the conflict and used for this the term "effective control" (Deiaki, 2017).

In Resolution № 2198 of January 23, 2018, the PACE defined Russian aggression in Donetsk and Luhansk oblasts as "the ongoing Russian war against Ukraine." These territories are defined as temporarily occupied, but they are controlled by illegal armed groups. The applicability to the war of Russia against Ukraine of the IV Geneva Convention Relative to the Protection of Civilian Persons in Time of War was indicated (Humanitarian, 2018). 
In a 2019 report on its preliminary investigations, the International Criminal Court noted the "direct military engagement between the respective armed forces of the Russian Federation and Ukraine, indicated the existence of an international armed conflict in eastern Ukraine from 14 July 2014 at the latest, in parallel to the non-international armed conflict," which lasts at least from April 30, 2014 and the parties to which are Ukraine, "LPR" and "DPR" (International, 2019). At the same time, this statement and its context do not in themselves give grounds to claim that this is an established fact. Also in 2016 - 2019 ICC reports pointed to the information consideration on "allegations that the Russian Federation has exercised overall control over armed groups in eastern Ukraine" during part or all times of armed conflict (International, 2016).

In the judgement Khlebikv. Ukraine in 2017 ECHR established the negative side of the control over Donbas issue stating that Ukrainian authorities in 2014 lost the control over certain territories and it is exercised by other subject not named in the decision ("the areas the Government do not control," "forces controlling the territory not under the Government's control," "non-Government-controlled areas"). And therefore Ukraine can't held all the responsibility for the events there: "The applicant did not argue that the lack of a mechanism for the Luhansk Region was due to a shortcoming on the part of the Ukrainian authorities rather than any other party" (European Court, 2017). The same formulations are presented in judgement Tsezar and Others $v$. Ukraine in 2018 ("the areas the Government do not control," "the territory not controlled by the Government," "the territories currently outside the control of the Government," "the non-controlled territory" (European Court, 2018).

The positive definition of the subject exercising the de facto control over certain Donbas territories not controlled by the Ukrainian authorities has to be brought, inter alia, in the ECHR decision on the case Ukraine v. Russia (Application no. 8019/16). On 27 November, 2020 the Grand Chamber announced the merger of this case with two others. The new case will be referred to as Ukraine and the Netherlands $v$. Russia (Nos. 8019/16, 43800/14 and 28525/20) (European Court Joins, 2020).

There are all reasons to expect the judgement stating the de facto control over certain Donbas territories taking into the account the ECHR decision on the Russian effective control, jurisdiction and "administrative practice" over Crimea before its manifested accession to the Russian Federation, namely from 27 February to 18 March 2014 (Ukraine v. Russia (re Crimea), Applications nos. 20958/14 and 38334/18):

"... there is sufficient evidence for the Court to conclude that during the relevant period the respondent State exercised effective control over Crimea. It is therefore not necessary, for the purposes of establishing "jurisdiction" under Article 1, to determine whether the respondent State exercised detailed control over the policies and actions of the local administration... the alleged victims of the administrative practice complained of by the applicant Government fall within the "jurisdiction" of the respondent State..." (European Court, 2020).

\section{CONCLUSIONS}

International law for more than a century provides for the possibility of separate regulation of the sovereignty and legal rights of the state to the territory, on the one 
hand, and the implementation of the regime of illegal control over the territory - on the other. The latter scholars call occupation law. The occupation does not envisage a change in the state affiliation of the occupied territory, and the entire civilian population is recognized as protected persons, and their minimum rights are determined.

But in the modern sense, primarily developed by doctrine and courts, illegal control over the territory can be considered as a legal regime, one of the forms of which is occupation, while others are defined as effective, overall, general, de facto control and related to undisclosed actions and informal means used by the aggressor states. This regime is characterized by the exercise of power over the territory by the will of a foreign state, and the forms of implementation of the regime differ depending on whether such a will is officially recognized or concealed.

The transformation of international humanitarian law after the Second World War erased the boundaries between recognized and officially unrecognized occupation, the dependence of the rights of the population in the occupied territories on the presence or absence of diplomatic relations between the states - occupying one and the victim of the occupation. It is also important that the occupation is associated with the performance of government functions in the occupied territory, but the status of the latter does not change from the introduction of changes in its administration or the conclusion of agreements between the occupying state and the de facto power of the territory.

Effective, overall, general, de facto control are forms that are separated from occupation, but not clearly demarcated between themselves. Unlike occupation, the fact of which may be obvious, the fact of effective or other control over the territory requires the determination by judicial authorities. The main indicators here are the realization by a foreign state of financial support, military supplies/equipment, training, coordination of actions or participation in action planning of armed groups that control the territory or part of the territory of another state and exercise de facto power there.

Notwithstanding the differences between occupation and effective or other control of a territory, international law in all these cases recognizes the extension to the occupied or otherwise illegally controlled territory of the jurisdiction of the State exercising that control. Accordingly, in this territory, in particular, the effect is preserved of international treaty legal instruments, the parties to which are both the sovereign state and the state, which exercises illegal control over the territory.

The qualification of illegal control by the Russian Federation of the territory of certain districts of Donetsk and Luhansk oblasts in the legislation of Ukraine has changed significantly. In 2014, along with the unequivocal proclamation of the temporary occupation of the Autonomous Republic of Crimea and Sevastopol, the armed conflict in eastern Ukraine was defined as the crisis situation and the anti-terrorist operation. Since 2015, it has been defined as the de facto Russian occupation and at the same time the control of terrorist organizations or gangs with the support of the Russian Federation. Finally, in 2018, a number of provisions of the laws on the occupied Crimea were extended to ORDLO, indicating the occupation and at the same time the exercise of general control by the Russian Federation. The duality of the latter wording, in our opinion, is justified in connection with the binding of most norms of international humanitarian law to the occupation regime. 
The qualification of ORDLO status in international law is also ambiguous. The Minsk agreements of 2014 avoided defining the other side of the conflict (the first is Ukraine), and in 2015 the armed formations of the ORDLO were named the second side. It is not specified to whom they are subordinated and who can be considered representatives of ORDLO. PACE resolutions recognize the dual fact of Russia's temporary occupation of ORDLO and its effective control over illegal armed groups in the territory. It is important that the PACE points to the applicability of IV Geneva Convention of 1949 to the armed conflict in Ukraine, and in particular to the situation in ORDLO. At the same time, full recognition of the international armed conflict between Ukraine and Russia in ORDLO, as well as Russia's illegal control over ORDLO (in the forms of occupation, effective or other control) should be expected in the process of consideration of a number of cases in the UN International Court of Justice, the International Criminal Court, the European Court of Human Rights.

\section{REFERENCES}

Advisory opinion of the International Court of Justice on the Legal Consequences of the Construction of a Wall in the Occupied Palestinian Territory. № 131. 9 July 2004, https://www.un.org/ unispal/document/auto-insert-178825/.

Annex to Convention (IV) Respecting the Laws and Customs of War on Land. Regulations concerning the Laws and Customs of War on Land. The Hague, 18 October 1907, https://ihldatabases.icrc.org/applic/ihl/ihl.nsf/0/1d1726425f6955aec125641e0038bfd6.

Brownlie I. (2003), Principles of public international law. $6^{\text {th }}$ ed. New York. Commentary of 1958 , https://ihl-databases.icrc.org/applic/ihl/ihl.nsf/Comment.xsp?action=openDocument\& docu mentId=5AA133B15493D9D0C12563CD0042A15A/.

Convention (IV) Relative to the Protection of Civilian Persons in Time of War. Geneva, 12 August 1949, https://www.un.org/en/genocideprevention/documents/atrocity-crimes/Doc.33_ GC-IV-EN.pdf.

Convention (IV) respecting the Laws and Customs of War on Land. The Hague, 18 October 1907, https://ihl-databases.icrc.org/applic/ihl/ihl.nsf/0/1d1726425f6955aec125641e0038bfd6.

Council of Europe: Parliamentary Assembly. Committee on Legal Affairs and Human Rights. Legal remedies for human rights violations on the Ukrainian territories outside the control of the Ukrainian authorities. Report. Rapporteur: Ms Marieluise Beck. 26 September 2016. Doc. 14139, https://www.refworld.org/docid/5836f4394.html.

De Mulinen F. (1987), Handbook on the Law of War for Armed Forces, Geneva.

Declaration on Principles of International Law concerning Friendly Relations and Co-operation among States in accordance with the Charter of the United Nations. UN General Assembly Resolution $2625(X X V) .24$ October 1970, https://undocs.org/en/A/RES/2625(XXV).

Definition of Aggression. UN General Assembly Resolution 3314 (XXIX). 14 December 1974, https:// undocs.org/en/A/RES/3314(XXIX).

Deiaki roziasnennia shchodo rezoliutsii PACE vid 12.10.2016. 07.02.2017, https://mtot.gov.ua/ua/ deyaki-roz-yasnennya-shhodo-rezolyutsiyi-parye-vid-12-10-2016.

European Court of Human Rights. Case of Ilaşcu and Others v. Moldova and Russia (Application no. 48787/99). Judgment. Strasbourg, 8 July 2004, https://hudoc.echr.coe.int/eng\# $\{\% 22$ item id\%22:[\%22001-61886\%22]\}. 
European Court of Human Rights. Grand Chamber. Case Al-Skeini and Others v. The United Kingdom (Application no. 55721/07). Judgment. Strasbourg, 7 July 2011, https://hudoc.echr.coe. int/fre\#\{\%22itemid\%22:[\%22001-105606\%22]\}.

European Court of Human Rights. Fourth Section. Case of Khlebik v. Ukraine (Application no. 2945/16). Judgment. Strasbourg, 25 July 2017, https://hudoc.echr.coe.int/eng\#\{\%22ite mid\%22:[\%22001-175656\%22]\}.

European Court of Human Rights. Fourth Section. Case of Tsezar and Others v. Ukraine (Applications nos. 73590/14, 73593/14, 73820/14, 4635/15, 5200/15, 5206/15 and 7289/15). Judgment. Strasbourg, 13 February 2018, https://laweuro.com/?p=9095.

European Court of Human Rights. Grand Chamber. Decision. Ukraine v. Russia (re Crimea). Applications nos. 20958/14 and 38334/18. Strasbourg, 16 December 2020, https://hudoc.echr. coe.int/eng\#_Toc60998548.

European Court joins three inter-State cases concerning Eastern Ukraine. ECHR 354 (2020). 04.12.2020, http://hudoc.echr.coe.int/app/conversion/pdf/?library=ECHR\&id=0036875827-9221606\&filename=European\%20Court\%20joins\%20three\%20inter-State $\% 20$ applications.pdf.

Formuliuvannia "efektyvnyi kontrol" v mizhderzhavnykh zaiavakh Ukrainy proty Rosii daie shans vyhravaty spravy v ECHR. 10.02.2017, https://mtot.gov.ua/ua/ponyattya-efektyvnyj-kontrolv-mizhderzhavnyh-zayavah-ukrayiny-proty-rosijskoyi-federatsiyi.

Humanitarian consequences of the war in Ukraine. Council of Europe. Parliamentary Assembly. Resolution 2198 (2018). 23 January 2018, https://assembly.coe.int/nw/xml/XRef/Xref-XML2HTML-en.asp?fileid=24432\&lang=en.

International Criminal Court. Report on Preliminary Examination Activities (2019). 5 December 2019, https://www.icc-cpi.int/Pages/item.aspx?name=191205-rep-otp-PE.

International Criminal Court. Report on Preliminary Examination Activities (2016). 14 November 2016, https://www.icc-cpi.int/pages/item.aspx?name=161114-otp-rep-PE.

International Tribunal for the Prosecution of Persons Responsible for Serious Violations of International Humanitarian Law Committed in the Territory of The Former Yugoslavia since 1991. Case No. IT-95-14-T. The Prosecutor v. Tihomir Blaškic. Date: 3 March 2000, https://www. icty.org/x/cases/blaskic/tjug/en/bla-tj000303e.pdf.

International Tribunal for the Prosecution of Persons Responsible for Serious Violations of International Humanitarian Law Committed in the Territory of The Former Yugoslavia since 1991. Case No.: IT-94-1-A. The Prosecutor v. Duško Tadić (Appeal Judgment). Date: 15 July 1999, https://www.icty.org/x/cases/tadic/acjug/en/tad-aj990715e.pdf.

Kompleks mer po vypolneniiu Minskih soglashenii. 12 fevralia 2015, https://www.osce.org/files/f/ documents/5/b/140221.pdf.

Legal remedies for human rights violations on the Ukrainian territories outside the control of the Ukrainian authorities. Council of Europe. Parliamentary Assembly. Resolution 2133 (2016), https://pace.coe.int/pdf/20d22932f59d66ff5a2dd4340a35fd4b6e328f033326667a8259ffe25 682ae848428feba12/resolution\%202133.pdf.

Lishchyna I. Iu. (2016), Rozghliad pozoviv Ukrainy proty Rosii v ECHR. Problemy ta perspektyvy rozghliadu, https://uba.ua/documents/events/2016_JUDICIAL_FORUM/Ivan_Lishchyna.pdf.

Memorandum ob ispolnenii polozhenii Protokola po itogam konsultatsyi Trekhstoronnei kontaktnoi gruppy otnosytelno sovmestnykh shagov, napravlennykh na implementatsyiu Mirnogo plana Prezidenta Ukrainy P. Poroshenko i initsiativ Prezidenta Rossii V. Putina. 19 sentiabria 2014, https://www.osce.org/files/f/documents/a/1/123807.pdf.

Minski uhody: yurydychnyi status ta oboviazkovist vykonannia. 20.01.2017, https://mtot.gov.ua/ua/ minski-ugody-yurydychnyj-status-ta-obov-yazkovist-vykonannya. 
Mizhnarodnyi Sud OON v the Hague: Ukraina proty Rosii. 09.03.2017, https://mtot.gov.ua/ua/mizhnarodnyj-sud-oon-v-gaazi-ukrayina-proty-rosiyi.

Okupatsiia ta efektyvnyi kontrol: natsionalne spryiniattia ta mizhnarodno-pravovi realii. 23.01.2017, https:/mtot.gov.ua/ua/okupatsiya-ta-efektyvnyj-kontrol-natsionalne-spryjnyattya-ta-mizhnarodno-pravovi-realiyi.

Political consequences of the Russian aggression in Ukraine. Council of Europe. Parliamentary Assembly. Resolution 2132 (2016), https://pace.coe.int/en/files/23166/html.

Protocol Additional to the Geneva Conventions of 12 August 1949, and Relating to the Protection of Victims of International Armed Conflicts (Protocol I). 1977, https://treaties.un.org/doc/Publication/UNTS/Volume\%201125/volume-1125-I-17512-English.pdf\#page=11.

Protokol po itogam konsultatsyi Trekhstoronnei kontaktnoi gruppy otnosytelno sovmestnykh shagov, napravlennykh na implementatsyiu Mirnogo plana Prezidenta Ukrainy P. Poroshenko i initsiativ Prezidenta Rossii V. Putina. 5 sentiabria 2014, https://www.osce.org/ru/home/123258.

Resolution 2166 (2014), Adopted by the Security Council at its 7221st meeting, on 21 July 2014, file:///C:/Users/User/Downloads/S_RES_2166(2014)-EN.pdf.

Resolution 2202 (2015), Adopted by the Security Council at its 7384th meeting, on 17 February 2015, https://www.securitycouncilreport.org/atf/cf/\%7B65BFCF9B-6D27-4E9C-8CD3CF6E4FF96FF9\%7D/s_res_2202.pdf.

Responsibility of States for internationally wrongful acts. UN General Assembly Resolution 56/83. 1983, https://undocs.org/en/A/RES/56/83.

Rosiyska Federatsiia vidpovidalna za pidtrymku separatystskoho rezhymu - Yevropeiskyi sud z prav liudyny. 07.09.2016, https://mtot.gov.ua/ua/rosijska-federatsiya-vidpovidalna-za-pidtrymkuseparatystskogo-rezhymu-yevropejskyj-sud-z-prav-lyudyny.

Tolstyh V. L. (2010), Kurs mezhdunarodnogo prava, Moscow.

Vitoshynskyi B. (2014), Viina i mizhnarodne pravo, Ukrainska vydavnycha spilka im. Yu. Lypy, Kyiv.

Zadorozhnii O. V. (2015), Porushennia ahresyvnoiu viinoiu Rosiiskoi Federatsii proty Ukrainy osnovnykh pryntsypiv mizhnarodnoho prava: monohrafia, Kyiv.

\begin{abstract}
Total rejection of the aggression and territory occupation in the international law leads to their hybrid and concealed forms using gangs and mercenaries, proclaiming new "states" etc. These activities constitute serious threat to international security, can cause and already cause the fragmentation of states, anarchy, criminalization of politics, new forms of expansionism and so on. The authors of the article generalize the forms of illegal control over the territory in international law and their application considering the status of Donbas determination.

International law for more than a century provides for the possibility of separate regulation of the sovereignty and legal rights of the state to the territory, on the one hand, and the implementation of the regime of illegal control over the territory - on the other. Authors argue that in the modern sense, primarily developed by doctrine and courts, illegal control over the territory can be considered as a legal regime, one of the forms of which is occupation, while others are defined as effective, overall, general, de facto control and related to undisclosed actions and informal means used by the aggressor states. This regime is characterized by the exercise of power over the territory by the will of a foreign state, and the forms of implementation of the regime differ depending on whether such a will is officially recognized or concealed.
\end{abstract}


The transformation of international humanitarian law after the Second World War erased the boundaries between recognized and officially unrecognized occupation. But unlike occupation, the fact of which may be obvious, the fact of effective or other control over the territory requires the determination by judicial authorities.

The qualification of illegal control by the Russian Federation of the Donbas in national and international law is ambiguous. The authors argue that the full recognition of the international armed conflict between Ukraine and Russia in Donbas, as well as Russia's illegal control over latter should be expected in the process of consideration of a number of cases in the international judicial institutions.

Keywords: international law, international humanitarian law, illegal control over territory, occupation, aggression, effective control, de facto control, general control

\section{NIELEGALNA KONTROLA TERYTORIUM W PRAWIE MIĘDZYNARODOWYM ORAZ USTALENIE STATUSU DONBASU}

\section{STRESZCZENIE}

Całkowite odrzucenie agresji i okupacji terytoriów w prawie międzynarodowym prowadzi do ich hybrydowych i ukrytych form wykorzystujących gangi i najemników, proklamowania nowych ,państw” itp. Działania te stanowią poważne zagrożenie dla bezpieczeństwa międzynarodowego, mogą powodować i już powodują m.in. fragmentację państw, anarchię, kryminalizację polityki oraz nowe formy ekspansjonizmu. Autorzy artykułu uogólniają formy nielegalnej kontroli terytorium w prawie międzynarodowym i ich stosowanie $\mathrm{z}$ uwzględnieniem stanu determinacji Donbasu.

Prawo międzynarodowe od ponad wieku przewiduje możliwość odrębnego uregulowania suwerenności i praw państwa do terytorium z jednej strony, a wprowadzenie reżimu nielegalnej kontroli nad terytorium $-\mathrm{z}$ drugiej. Autorzy argumentują, że we współczesnym rozumieniu wypracowanym przede wszystkim przez doktrynę i sądy, nielegalną kontrolę nad terytorium można uznać za reżim prawny, którego jedną z form jest okupacja, podczas gdy inne określa się jako skuteczne, całościowe, ogólne, de facto kontroli i związane z nieujawnionymi działaniami i nieformalnymi środkami stosowanymi przez państwo agresora. Reżim ten charakteryzuje się sprawowaniem władzy nad terytorium z woli obcego państwa, a formy realizacji reżimu różnią się w zależności od tego, czy taka wola jest oficjalnie uznana, czy zatajona.

Transformacja międzynarodowego prawa humanitarnego po II wojnie światowej zatarła granice między uznaną i oficjalnie nieuznaną okupacją. Ale w przeciwieństwie do okupacji, której fakt może być oczywisty, fakt skutecznej lub innej kontroli nad terytorium wymaga ustalenia przez organy sądowe.

Kwalifikacja nielegalnej kontroli Federacji Rosyjskiej nad Donbasem w prawie krajowym i międzynarodowym jest niejednoznaczna. Autorzy argumentują, że pełnego uznania międzynarodowego konfliktu zbrojnego między Ukrainą a Rosją w Donbasie, a także nielegalnej kontroli Rosji nad tym ostatnim, należy się spodziewać w procesie rozpatrywania szeregu spraw w międzynarodowych instytucjach sądowych.

Słowa kluczowe: prawo międzynarodowe, międzynarodowe prawo humanitarne, nielegalna kontrola terytorium, okupacja, agresja, skuteczna kontrola, de facto kontrola, kontrola ogólna 